Media Informatika, Vol. 3, No. 1, Juni 2005, 61-68

ISSN: 0854-4743

\title{
PERAN TEKNOLOGI INFORMASI DALAM MODERNISASI PENDIDIKAN BANGSA*
}

\author{
Fathul Wahid \\ Laboratorium Sistem Informasi dan Rekayasa Perangkat Lunak (SIRKEL), \\ Jurusan Teknik Informatika, Fakultas Teknologi Industri, Universitas Islam Indonesia \\ Jl. Kaliurang Km. 14 Yogyakarta 55501 \\ Telp. (0274) 895287 ext. 122, Faks. (0274) 895007 ext. 148 \\ E-mail: fathulwahid@fti.uii.ac.id
}

\begin{abstract}
ABSTRAK
Tulisan ini membahas potensi teknologi informasi dan dampaknya terhadap modernisasi pendidikan. Dampak teknologi informasi secara umum dapat dilihat jawaban dari tiga pertanyaan (1) bagaimana kita belajar (how people learn); (2) apa yang kita pelajari (what people learn); dan (3) kapan dan di mana kita belajar (where and when people learn). Ketiga jawaban ini terkait dengan tren pemanfaatan teknologi informasi dalam proses pembelajaran yang dikenal dengan e-learning. Isu-isu terkait dengan masalah yang mungkin ditimbulkan dari pemanfaatan teknologi informasi di sektor pendidikan juga didiskusikan.
\end{abstract}

Kata-kunci: teknologi informasi, pendidikan, e-learning

\section{PENDAHULUAN}

Perubahan lingkungan luar dunia pendidikan, mulai lingkungan sosial, ekonomi, teknologi, sampai politik mengharuskan dunia pendidikan memikirkan kembali bagaimana perubahan tersebut mempengaruhinya sebagai sebuah institusi sosial dan bagaimana harus berinteraksi dengan perubahan tersebut. Salah satu perubahan lingkungan yang sangat mempengaruhi dunia pendidikan adalah hadirnya teknologi informasi (TI).

TI telah menghadirkan media baru dalam penyebaran informasi, yaitu media digital. Informasi yang tidak lagi disusun atas atom-atom - tetapi dalam bitbit (Negroponte, 1998) - telah mempercepat dan mempermudah proses penyebarannya. Media ini pun telah mengubah pola pikir manusia yang merupakan respon terhadap kemasan informasi. Contoh perubahan pola pikir tersebut adalah lahirnya e-mail yang mengubah cara berkirim surat, e-business atau e-commerce yang telah mengubah cara berbisnis dengan segala turunannya, termasuk e-cash atau e-money. E-government telah membuka babak baru pengelolaan pemerintahan dan mekanisme hubungan antara pemerintah, dunia bisnis, dan masyarakat. E-learning menawarkan cakrawala baru proses belajar-

* Versi awal tulisan ini pernah dipresentasikan dalam Simposium Nasional Peduli Pendidikan yang diadakan oleh pendidikan@yahoogroups.com, di Fakultas Teknologi Industri, Universitas Islam Indonesia, Yogyakarta, pada 9 Juli 2005. 
mengajar. Perubahan-perubahan tersebut terus berlangsung dan dalam beberapa bidang sudah mulai mapan, terutama di negara-negara maju.

Data Departemen Pendidikan Nasional menunjukkan bahwa sebanyak 90\% SMU dan 95\% SMK telah memiliki komputer. Namun demikian, kurang dari 25\% SMU dan 10\% SMK yang telah terhubungan dengan Internet (Mohandas, 2003). Di tingkat perguruan tinggi, data Direktorat Jenderal Pendidikan Tinggi - dalam Pannen (2005) - menunjukkan bahwa kesadaran dalam pemanfaatan TI dalam proses pembelajaran masih sangat rendah. Analisis terhadap proposal teaching grant, baru $29,69 \%$ yang memanfatkan media berbasis teknologi komputer. Ketersedian media berbasis teknologi informasi juga masih terbatas. Hanya $15,54 \%$ perguruan tinggi negeri (PTN) dan 16,09\% perguruan tinggi swasta (PTS) yang memiliki ketersediaan media berbasis teknologi informasi. Sekitar 16,65\% mahasiswa dan 14,59\% dosen yang mempunyai akses terhadap teknologi informasi. Hasil survei yang melihat pemanfaatan TI pada tahun 2004 menunjukkan bahwa baru 17,01\% PTN, 15,44\% PTS, 9,65\% dosen, dan 16,17\% mahasiswayang memanfaatkan TI dengan baik. Secara keseluruhan statistik ini menunjukkan bahwa adopsi TI dalam dunia pendidikan di Indonesia masih rendah.

Tulisan singkat ini dimaksudkan untuk menjawab pertanyaan-pertanyaan terkait dengan (a) bagaimana seharusnya kita memandang TI, termasuk potensi apa yang ditawarkan oleh TI; dan (b) bagaimana peran TI dalam modernisasi/reformasi pendidikan.

\section{PARADIGMA PEMANFAATAN TEKNOLOGI INFORMASI}

Yang perlu diperhatikan sejak awal adalah bahwa penggunaan TI tidak sama dengan otomatisasi. TI tidak hanya memecahkan masalah dengan menggantikan pekerjaan yang selama ini dilakukan dengan manual menjadi berbantuan teknologi. Jika paradigma berpikir itu yang digunakan, maka pemanfaatan TI, menurut Hammer dan Champy (1993), tidak akan membawa perubahan radikal. Cara berpikir deduktif (deductive thinking) seperti ini tidak banyak memunculkan perubahan yang radikal terkait dengan pemanfaatan TI dibandingkan jika berpikir secara induktif (inductive thinking).

Orang yang berpikir secara deduktif, pertama kali mencari masalah yang akan dipecahkan dan kemudian mengevaluasi sejumlah alternatif solusi yang akan digunakan. Jika TI ingin dioptimalkan pemanfaatannya dalam organisasi maka manajer/pemimpin harus berpikir induktif. Potensi TI harus dikenali dengan baik terlebih dahulu, kemudian mencari masalah yang mungkin dipecahkan. Masalah ini mungkin bahkan tidak dikenali sebelumnya atau tidak dianggap sebagai masalah.

Pertanyaan yang harus dimunculkan bukannya, "Bagaimana kita dapat menggunakan kemampuan TI untuk meningkatkan apa yang telah kita kerjakan?", tetapi "Bagaimana kita dapat menggunakan TI untuk mengerjakan apa yang belum kita kerjakan?." Pertanyaan yang pertama lebih terkait dengan otomatisasi, yang juga dapat meningkatkan efisiensi, namun tidak sebaik yang 
dihasilkan oleh rekayasa-ulang (reengineering) berbantuan TI. Rekayasa ulang ini banyak dilakukan oleh dunia industri.

Dengan sudut pandang yang lain, Davenport dan Short (1990) mendefinisikan 10 peran yang dapat dimainkan oleh TI, yaitu transactional, geographical, automatical, analytical, informational, sequential, knowledge management, tracking, dan disintermediation. Semua peran TI ini dapat dikontekstualisasikan dengan kebutuhan dunia pendidikan. Dalam bahasa yang lain, Al-Mashari dan Zairi (2000) menyatakan bahwa manfaat TI adalah pada kemampuannya yang (1) enabling parallelism; (2) facilitating integration; (3) enhancing decision making; dan (4) minimizing points of contact.

Pemahaman terhadap peran yang dapat dimainkan oleh TI atau potensi yang ditawarkan oleh TI merupakan modal awal dalam berpikir induktif. Dengan demikian, akhirnya, TI dapat diekspoitasi untuk mendapatkan manfaat yang maksimal.

\section{PERAN TEKNOLOGI INFORMASI DALAM MODERNISASI PENDIDIKAN}

Menurut Resnick (2002) ada tiga hal penting yang harus dipikirkan ulang terkait dengan modernisasi pendidikan: (1) bagaimana kita belajar (how people learn); (2) apa yang kita pelajari (what people learn); dan (3) kapan dan dimana kita belajar (where and when people learn). Dengan mencermati jawaban atas ketiga pertanyaan ini, dan potensi TI yang bisa dimanfaatkan seperti telah diuraikan sebelumnya, maka peran TI dalam moderninasi pendidikan bangsa dapat dirumuskan. Hubungan antara TI dan reformasi pendidikan secara grafis diilustrasikan pada Gambar 1.

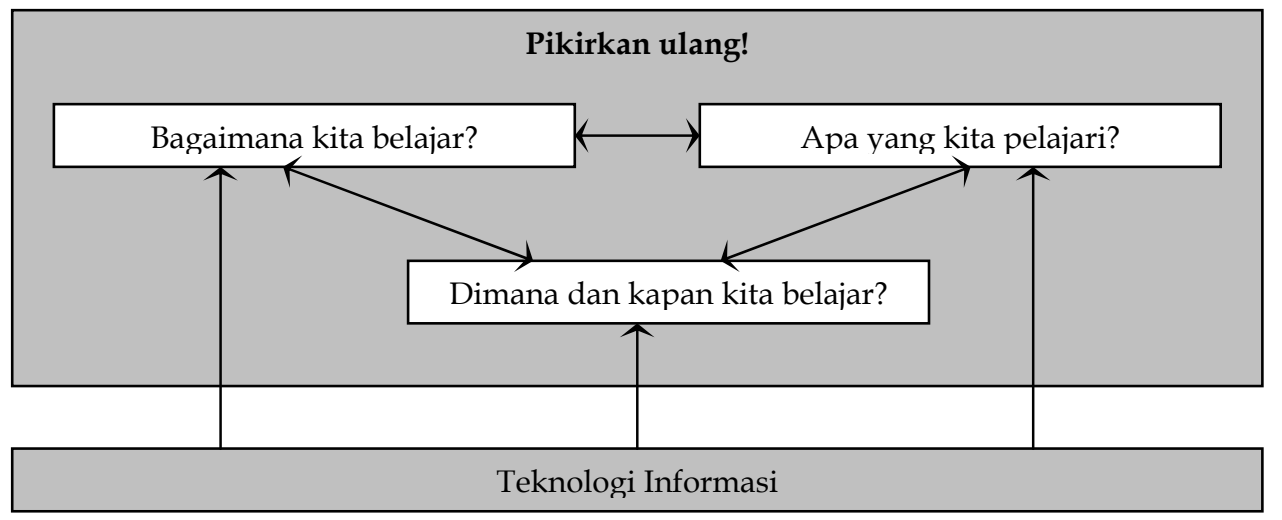

Gambar 1. Intervensi TI dalam reformasi pendidikan

Pertanyaan pertama, bagaimana kita belajar, terkait dengan metode atau model pembelajaran. Cara berinteraksi antara guru dengan siswa sangat menentukan model pembelajaran. Terkait dengan ini, menurut Pannen (2005), saat ini terjadi perubahan paradigma pembelajaran terkait dengan ketergantungan 
terhadap guru dan peran guru dalam proses pembelajaran. Proses pembelajaran seharusnya tidak $100 \%$ bergantung kepada guru lagi (instructor dependent) tetapi lebih banyak terpusat kepada siswa (student-centered learning atau instructor independent). Guru juga tidak lagi dijadikan satu-satunya rujukan semua pengetahuan tetapi lebih sebagai fasilitator atau konsultan (Resnick, 2002).

Intervensi yang bisa dilakukan TI dalam model pembelajaran ini sangat jelas. Hadirnya e-learning dengan semua variasi tingkatannya telah memfasilitasi perubahan ini. Secara umum, e-learning dapat didefinisikan sebagai pembelajaran yang disampaikan melalui semua media elektronik termasuk, Internet, intranet, extranet, satelit, audio/video tape, TV interaktif, dan CD ROM (Govindasamy, 2002). Menurut Kirkpatrick (2001), e-learning telah mendorong demokratisasi pengajaran dan proses pembelajaran dengan memberikan kendali yang lebih besar dalam pembelajaran kepada siswa. Hal ini sangat sesuai dengan prinsip penyelenggaraan pendidikan nasional seperti termaktub dalam Pasal 4 UndangUndang Nomor 20 Tahun 2003 tentang Sistem Pendidikan Nasional yang menyatakan bahwa "pendidikan diselenggarakan secara demokratis dan berkeadilan serta tidak diskriminatif dengan menjunjung tinggi hak asasi manusia, nilai keagamaan, nilai kultural, dan kemajemukan bangsa".

Secara umum, intervensi e-learning dalam proses pembelajaran dapat dikelompokkan menjadi dua: komplementer dan substitusi. Yang pertama mengandaikan bahwa cara pembelajaran dengan pertemuan tatap-muka masih berjalan tetapi ditambah dengan model interaksi berbantuan TI, sedang yang kedua sebagian besar proses pembelajaran dilakukan berbantuan TI. Saat ini, regulasi yang dikeluarkan oleh pemerintah juga telah memfasilitasi pemanfaatan e-learning sebagai substitusi proses pembelajaran konvensional. Surat Keputusan Menteri Pendidikan Nasional No. 107/U/2001 dengan jelas membuka koridor untuk menyelenggarakan pendidikan jarak jauh di mana e-learning dapat masuk memainkan peran.

Pertanyaan selanjutnya adalah apa yang kita pelajari. Pertanyaan-pertanyaan seperti apakah kurikulum telah sesuai dengan kebutuhan siswa dan apakah kurikulum telah dirancang untuk menyiapkan siswa untuk hidup dan bekerja pada masa yang akan datang perlu sekali lagi dilontarkan. Perkembangan TI yang sangat pesat harus dipertimbangkan dalam menjawab pertanyaan-pertanyaan ini. Menurut Resnick (2002), selain TI akan sangat mewarnai masa depan, TI juga mengubah tidak hanya terhadap apa yang seharusnya dipelajari oleh siswa, tetapi juga apa yang dapat dipelajari. Sangat mungkin banyak hal yang seharusnya atau dapat dipelajari siswa tetapi tidak bisa dimasukkan ke dalam kurikulum karena "ruang" yang terbatas atau kompleksitas yang tinggi dalam mengajarkannya. Terkait dengan ini, paradigma pembelajaran yang sebelumnya mengandaikan bahwa sumberdaya pembelajaran hanya terbatas pada materi di kelas dan buku harus diubah. Hadirnya TI, terutama Internet, telah menyediakan sumberdaya pembelajaran yang tidak terbatas. Sebagai contoh, survei yang dilakukan oleh penulis pada siswa SMU di Yogyarta, Bantul, dan Gunungkidul menemukan bahwa lebih dari 10\% siswa menggunakan komputer untuk desain grafis yang tidak diajarkan di sekolah. Pertanyaan sederhana yang muncul adalah bagaimana 
mereka belajar? Jawabannya sangat lugas: akses terhadap komputer dan Internet telah memungkinkan hal itu terjadi. Contoh lain, yang tertarik dengan teknologi informasi tetapi tidak mempunyai kesempatan untuk duduk di bangku sekolah/kuliah bisa mengunjungi www.ilmukomputer.com yang menyediakan sumberdaya pembelajaran gratis.

Diskusi seperti ini dapat diperpanjang untuk tidak membatasi pembelajaran hanya pada institusi formal. Sudah saatnya learning society dikampanyekan sebagai salah satu manifestasi kesadaran semangat pembelajaran sepanjang hayat (long-life learning). Bukankah kita tidak jarang merasa tidak tahu apa yang harus dipelajari karena tidak tersedia sarana/informasi tentang itu? Karenanya, gerakan untuk membuka akses informasi dan pengetahuan seluas-seluasnya kepada masyarakat menjadi sebuah keharusan. Teknologi informasi, terutama Internet, dalam hal ini memberikan peluang untuk itu.

Kapan dan dimana belajar dilakukan adalah pertanyaan ketiga yang perlu dipikirkan kembali jawabannya. Apakah harus dalam ruangan kelas dalam waktu tertentu atau tidak terbatas ruang dan waktu? Model pembelajaran tatap-muka yang banyak membatasi waktu dan tempat belajar. Sebagai komplemen (atau substitusi), teknologi e-learning hadir untuk memberikan kebebasan kepada siswa dalam memilih tempat, waktu, dan ritme belajar (Kirkpatrick, 2004). Interaksi yang difasilitasi oleh TI ini dapat terjadi secara sinkron (pada waktu yang sama) maupun asinkron (dalam waktu yang berbeda).

E-learning dapat difasilitasi secara online maupun offline tetapi berbantuan TI. Produksi CD-ROM dengan konten materi pembelajaran termasuk di dalamnya. Kini, kita bisa dapatkan banyak CD-ROM untuk pembelajaran di pasaran; mulai untuk balita. Bahkan beberapa CD-ROM telah memfasilitasi siswa belajar sesuai dengan kurikulum yang sedang berjalan dengan kemasan yang menarik. Dalam hal ini, TI dapat menghadirkan digital excitement dalam proses pembelajaran. Salah satu perusahaan yang memproduksi CD-ROM semacam ini adalah Akal (www.akalinteraktif.com).

Untuk menfasilitasi e-learning dengan bantuan koneksi Internet, dalam beberapa tahun terakhir, telah dikembangkan banyak aplikasi yang dirancang untuk mendukung proses pembelajaran. Aplikasi ini sering disebut dengan Learning Management System (LMS). LMS ini mengintegrasikan banyak fungsi yang mendukung proses pembelajaran seperti menfasilitasi berbagai macam bentuk materi instruksional (teks, audio, video), e-mail, chat, diskusi online, forum, kuis, dan penugasan. Beberapa contoh LMS adalah WebCT (www.webct.com), Blackboard (www.blackboard. com), Macromedia Breeze (www.macromedia.com/software/breeze/), dan Fronter (www.fronter.no). LMS sudah banyak diadopsi oleh banyak lembaga pendidikan di dunia. Sebagi contoh, WebCT telah digunakan lebih dari 2200 PT di seluruh dunia (Pituch dan Lee, 2004). Blackboard juga sudah banyak digunakan oleh pendidikan setingkat SMU (www.blackboard.com).

Banyak kritik dialamatkan kepada penggunaan LMS yang dianggap tidak membertimbangkan aspek pedagogis. Karenanya, menurut Institute for Higher Education Policy, Amerika (dalam Govindasamy, 2002) terdapat tujuh parameter 
yang perlu diperhatikan dalam menerapkan e-learning yang mempertimbangkan prinsip-prinsip pedagogis, yaitu: (1) institutional support; (2) course development; (3) teaching and learning; (4) course structure; (5) student support; (6) faculty support; dan (7) evaluation and assessment. Karenanya, dalam bahasa yang lain, Soekartawi (2003) mengidentifikasi bahwa keberhasilan implementasi e-learning sangat tergantung kepada penilaian apakah: (a) e-learning itu sudah menjadikan suatu kebutuhan; (b) tersedianya infrastruktur pendukung seperti telepon dan listrik (c). tersedianya fasilitas jaringan internet dan koneksi Internet; (d) software pembelajaran (learning management system); (e) kemampuan dan ketrampilan orang yang mengoperasikannya; dan (f) kebijakan yang mendukung pelaksanaan program e-learning.

Dalam konteks yang lebih luas, yaitu dalam manajemen dunia pendidikan, berdasar studi tentang tujuan pemanfaatan TI di dunia pendidikan terkemuka di Amerika, Alavi dan Gallupe (2003) menemukan beberapa tujuan pemanfaatan TI, yaitu (1) memperbaiki competitive positioning; (2) meningkatkan brand image; (3) meningkatkan kualitas pembelajaran dan pengajaran; (4) meningkatkan kepuasan siswa; (5) meningkatkan pendapatan; (6) memperluas basis siswa; (7) meningkatkan kualitas pelayanan; (8) mengurangi biaya operasi; dan (9) mengembangkan produk dan layanan baru. Karenanya, tidak mengherankan jika saat ini banyak perguruan tinggi di Indonesia yang berlomba-lomba berinvestasi dalam bidang TI untuk memenangkan persaingan yang semakin ketat.

\section{MASALAH AKIBAT PENGGUNAAN TI}

Seperti teknologi lain yang telah hadir ke muka bumi ini, TI juga hadir dengan dialektika. Selain membawa banyak potensi manfaat, kehadiran TI juga dapat membawa masalah. Khususnya Internet, penyebaran informasi yang tidak mungkin terkendalikan telah membuka akses terhadap informasi yang tidak bermanfaat dan merusak moral. Karenanya, penyiapan etika siswa juga perlu dilakukan. Etika yang terinternalinasi dalam jiwa siswa adalah firewall terkuat dalam menghadang serangan informasi yang tidak berguna.

Masalah lain yang muncul terkait asimetri akses; akses yang tidak merata. Hal ini akan menjadikan kesenjangan digital (digital divide) semakin lebar antara siswa atau sekolah dengan dukungan sumberdaya yang kuat dengan siswa atau sekolah dengan sumberdaya yang terbatas (lihat juga Lie, 2004). Survei yang dilakukan oleh penulis pada Mei 2005 di tiga kota/kabupaten di Propinsi DI Yogyakarta terhadap 298 siswa dari 6 buah SMU yang berbeda menunjukkan bahwa akses terhadap komputer dan Internet di daerah kota (i.e. Kota Yogyakarta) jauh lebih baik dibandingkan dengan daerah pinggiran (i.e. Kabupaten Bantul dan Gunungkidul). Jika hanya sekolah swasta yang dianalisis, kesenjangan ini menjadi sangat tinggi. Akses siswa SMU swasta di Kota Yogyakarta terhadap komputer dan Internet secara signifikan jauh lebih tinggi dibandingkan dengan siswa SMU swasta di Kabupaten Bantul dan Gunungkidul. Minimal, hal ini memberikan sinyal adanya kesenjangan digital antar kelompok dalam masyarakat, baik dikategorikan menurut lokasi geografis maupun tingkat ekonomi. 
Untuk masalah kesenjangan ini, semua pihak (e.g. pemerintah, lembaga swadaya masyarakat (LSM), dunia pendidikan, dan industri) dapat mulai memikirkan program untuk meningkatkan dan memeratakan aksesterhadap teknologi informasi di dunia pendidikan. Program yang difasilitasi oleh Sekolah2000 (www.sekolah2000.or.id) dengan membagikan komputer layak pakai ke sekolah-sekolah adalah sebuah contoh menarik. Tentu saja program seperti ini harus diikuti dengan penyiapan infrastruktur lain seperti listrik dan telepon. Pelatihan-pelatihan untuk meningkatkan melek (literacy) TI juga pintu masuk lain yang perlu dipikirkan untuk meningkatkan pemahaman terhadap potensi TI, yang pada akhirnya diharapkan meningkatkan kesadaran (awareness). Tanpa awareness, pemanfaatan TI tidak optimal, dan yang lebih mengkhawatirkan lagi sulit untuk berkelanjutan (sustainable) ${ }^{1}$. Dalah kaitan ini, program untuk peningkatan awareness yang berkelanjutan seperti pendidikan berkelanjutan lewat berbagai media (e.g. pelatihan konvensional dan media massa) dan lomba website sekolah (seperti yang diadakan oleh Sekolah2000 setiap tahun) merupakan sebuah alternatif yang perlu dipikirkan.

\section{EPILOG}

TI bukanlah obat mujarab (panacea) untuk semua masalah. Karenanya, pemanfaatan TI tidak bisa bebas konteks. Analisis kebutuhan dan pemahaman terhadap potensi yang ditawarkan oleh TI menjadi sangat penting. Lebih dari itu, pemanfaatan TI juga harus diikuti dengan penyiapan aspek lain, seperti sumbedaya finansial dan manusia. Tanpanya, keberlanjutan dalam pemanfaatan TI dalam mendukung proses pembelajaran dalam rangka memajukan pendidikan nasional menjadi tidak optimal.

Terakhir, dengan atau tanpa TI, sudah seharusnya dunia pendidikan Indonesia selalu berbenah untuk selalu menjadi lebih baik demi anak-anak bangsa. Hal ini dapat dilakukan, di antaranya, dengan membuka akses seluasnyaluasnya untuk mengikuti pendidikan dan meningkatkan iklim demokratis dalam proses pembelajaran dengan memberikan kendali yang lebih besar kepada siswa.

\section{PUSTAKA}

Alavi, M., dan Gallupe, R. B. (2003). Using Information Technology in Learning: Case Studies in Business and Management Education Programs. Academy of Management Learning and Education, 2(2), 139-153.

\footnotetext{
${ }^{1}$ Banyak cerita menarik sekaligus memperihatikan yang penulis dapatkan: 1. Ketika seorang ekonom Bank Dunia, Shoba Shetty, meninjau sebuah SMU di Salatiga yang mendapatkan bantuan komputer, dia mendapatkan komputer dalam keadaan tidak terpakai dan disimpan supaya tidak digunakan oleh siswa. Penyebabnya, ternyata, adalah karena Kepada Sekolah melarang penggunaan komputer bantuan tersebut karena khawatir akan rusak. 2. Seorang kawan menceritakan anaknya yang mendapatkan tugas membuat kliping dari sekolah. Ketika anaknya memberikan print-out surat kabar online kepada gurunya, sang guru menganggap bahwa itu bukanlah kliping surat kabar. Ketika ada sebuah tugas mengarang, karangan yang ditulis dengan bantuan komputer dianggap gurunya tidak kreatif. Penulis yakin masih banyak cerita "pembodohan" seperti ini. Satu kesimpulan yang dapat diambil adalah: pengetahuan masyakarat terkait dengan pemanfaatan TI masih sangat rendah.
} 
Al-Mashari, M., dan Zairi, M. (2000). Creating a Fit Between BPR and IT Infrastructure: A Proposes Framework for Effective Implementation. The Internationa Journal of Flexible Manufacturing Systems, 12, 253-274.

Davenport, T. H., dan Short, J. E. (1990). The New Industrial Engineering: Information Technology and Business Process Redesign. Sloan Management Review (Summer), 11-27.

Govindasamy, T. (2002). Successful Implementation of e-Learning: Pedagogical Considerations. Internet and Higher Education, 4, 287-299.

Hammer, M., dan Champy, J. (1993). Reengineering the Corporation: A Manifesto for Business Revolution. New York: HarperBusiness.

Kirkpatrick, D. (2001). Who Owns the Curriculum? Dalam Brook, B., dan .Gilding, A. The Ethics and Equity of e-Learning in Higher Education. Melbourne: Equity and Social Justice, Victoria University, 41-48.

Lie, A. (2004). Pendidikan dalam Dinamika Globalisasi. Dalam Widiatono, T. D. Pendidikan Manusia Indonesia. Jakarta: Kompas dan Yayasan Toyota dan Astra, 217-231.

Mohandas, R. (2003). ICT and e-Learning in Indonesia. Presentasi di Tainan, Taiwan, 25-27 Maret.

Negroponte, N. (1998). Being Digital. Terjemahan, Bandung: Mizan.

Pannen, P. (2005). Pemanfaatan ICT dalam Pembelajaran. Presentasi pada Seminar Sun Commitment in Education and Research Industry, Jakarta, 29 Juni.

Pituch, K. A., dan Lee, Y.-k. (2004). The Influence of System Characteristics on eLearning Use. Computers $\mathcal{E}$ Education.

Resnick, M. (2002). Rethinking Learning in the Digital Age. Dalam Porter, M. E., Sachs, J. D., dan McArthur, J. W. The Global Information Technology Report 2001-2002: Readiness for the Networked World.

Soekartawi (2003). E-Learning di Indonesia dan Prospeknya di Masa Mendatang. Presentasi pada Seminar e-Learning perlu e-Library, Universitas Petra, Surabaya, 3 Februari. 